\title{
In Situ Germination and Early Seedling Growth of Wormwood (Artemisia annua L.)
}

\author{
Tahir Salisu Muhammad1, Inuwa Shehu Usman2, Maryam Duniya Katung2, \\ Muhammad Faguji Ishiyaku² \\ ${ }^{1}$ Department of Biological Sciences, Kaduna State University, Kaduna, Nigeria \\ ${ }^{2}$ Department of Plant Science, Ahmadu Bello University, Zaria, Nigeria \\ Email: stahir1990@gmail.com, smtahir@kasu.edu.ng
}

Received 8 April 2014; revised 6 May 2014; accepted 18 May 2014

Copyright (C) 2014 by authors and Scientific Research Publishing Inc.

This work is licensed under the Creative Commons Attribution International License (CC BY). http://creativecommons.org/licenses/by/4.0/

(c) (i) Open Access

\begin{abstract}
Experiments were conducted on the farm of Institute for Agricultural Research (IAR), Ahmadu Bello University, Zaria, during the 2012 hot season and 2013 cold season to determine the most effective treatment for rapid germination of Artemisia annua by subjecting the seeds to physical treatment by soaking in cold and warm water for $2,4 \& 6$ hours and $1,2 \& 3$ minutes, chemical treatment by soaking in $10 \%, 20 \%$ \& $30 \%$ Sulphuric $\mathrm{Acid}\left(\mathrm{H}_{2} \mathrm{SO}_{4}\right)$ for $1,2 \& 3$ minutes respectively and hormone treatment (GA3) by soaking in 100 pp, 200 pp, 300 pp \& 500 pp for $6,12 \& 24$ hours. Results of Analysis of Variance (ANOVA) indicated no significant difference between the seasons with respect to germination, shoot and root lengths $(p \geq 0.05)$. However, warm water treatment at $60^{\circ} \mathrm{C}$ for 2 minutes during the rainy season trial had the least days to germination. Similarly, warm water treatments in both rain and irrigation trials at $40^{\circ} \mathrm{C}$ for 3 minutes and $60^{\circ} \mathrm{C}$ for 3 minutes produced the best vigor. Highest germination percent $(96 \%)$ was observed during the rainy season trial with $10 \%$ Sulphuric acid treatment. Using warm water is a simple and affordable treatment especially to local farmers which will give the best result in the germination and seedling production of $\boldsymbol{A}$. annua. Early March is recommended as the ideal planting period so that seedlings are transplanted on the field at the onset of rainfall.
\end{abstract}

\section{Keywords}

Artemisia, In Situ, Germination, Seedling, Growth

\section{Introduction}

Artemisia annua L. (Wormwood) belongs to the tribe Anthemideae of the Asteroideae, a subfamily of the Asteraceae (Compositae) [1]. Its cultivation has expanded from its centre of origin (China) to Nigeria in response to 
the call by the World Health Organization for the use of Artemisinin-Combination Therapies (ACT) for treating malaria fever. Likewise its effectiveness has been demonstrated in the treatment of skin diseases and it has also been shown to be an effective non-selective herbicide such as glyphosate [2] [3].

Members of some plant families exhibit erratic germination due to seed dormancy [4]. They readily germinate within the native environment, but fail to show good germination under alien condition depending on the plant species and type of dormancy, several methods are used to break dormancy in order to induce germination [4]-[7].

Artemisia seeds were observed to undergo chemical dormancy due to the Presence of some chemical compounds (such as Phenolics) on the surface. This was linked with seeds germination inhibition and dormancy of the plant. Phenolics accumulation played a protective role in strengthening the plant cell walls during growth by polymerization into lignin [8]. In Nigeria, productive Artemisia seed is expensive and not readily available. Successful and quantitative production of biomass is an important step towards maximizing Artemisinin content in Artemisia for the treatment of malaria fever. However, this has been hindered by several biotic and abiotic factors such as the pest, diseases and climatic constraints. Consequently, this has led to poor performance, hence decrease in yields. Similarly, there is inadequate agro-technological information regarding the ideal planting dates, seed density, harvesting system, post-harvesting and optimum fertilizer application rates required for higher yields. There is therefore, the need to determine the most effective treatment for the germination of Artemisia seeds as a commercially viable means to production of Artemisinin.

\section{Materials and Methods}

\subsection{Study Area}

Two separate experiments were conducted during the 2012 \& 2013 hot and cold seasons respectively on farm of the Institute for Agricultural Research (IAR) Ahmadu Bello University, Zaria, latitude $11^{\circ} 11^{\prime} \mathrm{N}$ and $07^{\circ} 38^{\prime} \mathrm{E}$, altitude $670 \mathrm{~m}$ above sea level, $640 \mathrm{~km}$ from the Atlantic shores of Nigeria in the south.

\subsection{Materials}

Fresh and healthy seeds of Chinyong variety of Artemisia annua were sourced from the Artemisia Programme Unit in the Institute for Agricultural Research (IAR) Ahmadu Bello University, Zaria for the experiment.

\subsection{Treatments}

The seeds were subjected to the following treatments:

\section{1) Chemical Treatment}

Seeds were soaked into $10 \%, 20 \%$ \& $30 \%$ Sulphuric acid $\left(\mathrm{H}_{2} \mathrm{SO}_{4}\right)$ for 1 , 2 and 3 minutes respectively with a control (0\%).

\section{2) Hormone Treatment}

The seeds were soaked in three different GA3 concentrations (100 ppm, 300 ppm, \& 500 ppm) with a control (0\%) for 6 hrs, 12 hrs \& 24 hours respectively.

\section{3) Warm Water Treatment}

Seeds were soaked in water bath and incubated under $20^{\circ} \mathrm{C}, 40^{\circ} \mathrm{C}$ and $60^{\circ} \mathrm{C}$ for 1 minute, 3 minutes and 5 minutes respectively.

\section{4) Cold Water Treatment}

Seeds were washed and soaked in cold water for 2 hrs, 4 hrs $\& 6$ hrs before planting.

\subsection{Sowing}

The Artemisia seeds were sown in polythene bags containing sterilized river soil. [9]. Under the pre-nursery stage the seeds were sown in polythene bags containing sterilized river sand and monitored for germination. Transparent polythene material was used to cover the seeds. This is to help maintain adequate moisture, temperature and humidity levels in the soil, which are essential for Artemisia seed germination (Figure 1). Two weeks after germination, the tender seedlings were transferred to the nursery stage into a mixture of $50 \%$ each of river sand and cow dung to facilitate drainage and enhance their growth.

The germination percent was calculated according to [10] where $\mathrm{Gr}=$ (number germinating since $n-1) / n$. 
Where: $\mathrm{Gr}=$ germination rate; $\mathrm{n}=$ the days of incubation.

Seedling vigor was determined by field rating based on morphological appearance, seedling emergence and early percentage germination adopting the procedure of [11]. A scale of $1-5$ was used where $1=$ very high vigor and 5 = very low vigor.

\section{1) Watering}

While waiting for the Artemisia seeds to germinate and depending upon the humidity in the area, the soil was kept moist and damp by regular watering.

\section{2) Preparation of Seedlings}

Sixty days after germination, the plants were hardened gradually by exposing them to sunlight while reducing watering, prior to transplanting.

\section{3) Parameters Studied}

The following parameters were studied:

Days to germination;

Percentage germination;

Seedling vigor;

Seedling height;

Root length.

\subsection{Data Analysis}

The data generated from this work was analyzed using analysis of variance (ANOVA), SAS (2002) statistical package. Least significant difference (LSD) was also used to compare treatment means ( $\mathrm{p}<0.05)$.

\section{Results}

Covering the seeds with transparent polythene was observed to maintained suitable temperature and moisture condition thereby enhancing the germination of $A$. annua. These were seen to be very vital in the germination of this plant (Figure 1). During the 2012 study period, an average temperature of $37^{\circ} \mathrm{C}$, a humidity of $9 \%$ and

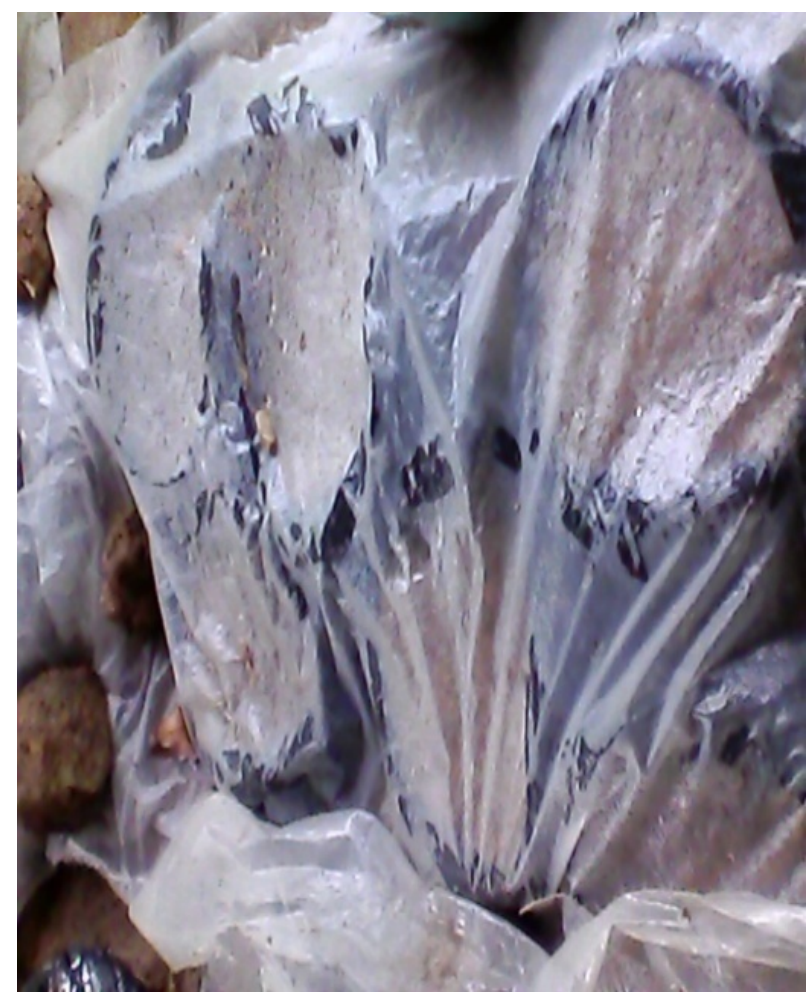

Figure 1. Seeds sawn and covered with transparent polythene. 
sunshine duration of 7 hours were recorded. However, $33^{\circ} \mathrm{C}$ temperature, $22 \%$ humidity and 8 hours sunshine duration were recorded for 2013 experiment. Hypogeal type of germination was observed to occur 2 - 3 days after sowing (Figure 1). Leaves were found to be aromatic, deeply dissected and range from 3.0 to $8.5 \mathrm{~cm}$ in length (Figure 2). Transferring the seedlings singly into bags containing a mixture of river sand and cow dung in the ratio of 50:50 was also observed to further facilitate the growth and development of A. annua (Figure 2). Results obtained from this study showed no significant difference between the seasons with respect to germination, shoot and root lengths. However, warm water treatment at $60^{\circ} \mathrm{C}$ for 2 minutes during the rainy season trial had the least days to germination (Table 1). Similarly, warm water treatments in both rain and irrigation trials at $40^{\circ} \mathrm{C}$ for 3 minutes and $60^{\circ} \mathrm{C}$ for 3 minutes produced the best vigor (Table 2). Highest germination percent (96\%) was observed during the rainy season trial with $10 \%$ Sulphuric acid treatment (Table 1). Fourteen days after germination, the young seedlings were transfrered to the nursery stage (Figure 3(b)).

\section{Discussion}

Germination is a vital phenomenon during the life cycle of a plant [12]. The early germination observed may be attributed to the covering with polythene material which helped in maintaining adequate moisture, warm and humidity levels in the soil, which are essential for Artemisia seed germination. Dormancy of some seeds was reported to be inhibited when soil temperatures are too warm. They therefore germinate only at high temperatures [13]. Similarly, germination depends on weakening of the seed coat by heating hence providing the optimum temperature suitable for influencing the rate of enzyme-controlled reactions [14] [15]. The chemical dormancy reported in Artemisia seeds due to the accumulation of some chemical compounds such as Phenolics on the surface, played a protective role in strengthening the plant cell walls during growth by polymerization into lignin. This physiologically contributes to the maintenance of dormancy by impeding water and gas to and from the embryo, chemically by inhibiting germination and mechanically by restricting the growth of the embryo [8] [15] [16]. This eventually serves as a barrier that restrict water uptake by the impermeable outer part of the epidermal layer of malphigian cells hence restraining expansion of the radicle and manifestation of germination [17].

The aromatic, deeply dissected leaves ranging from 3.0 to $8.5 \mathrm{~cm}$ in length observed, is similar to the findings of [18]. The germinating seeds of A. annua exhibited a hypogeal type of germination by having the Cotyledon remaining below the soil surface. A seed was considered germinated when the tip of the radicle had grown free of the seed coat emerging through the outer covering [10] [19]. Exposure of the shoot tip to light enabled it to photosynthesize thereby straightening the epicotyls [20] [21].

All treated seeds were covered with transparent polythene thereby exposing them to light which is an important regulatory environmental signal that triggers germination [22] and they responded favorably [23]. This is contrary to the findings of [24] who reported that seeds of A. annua germinated after exposure to dark.

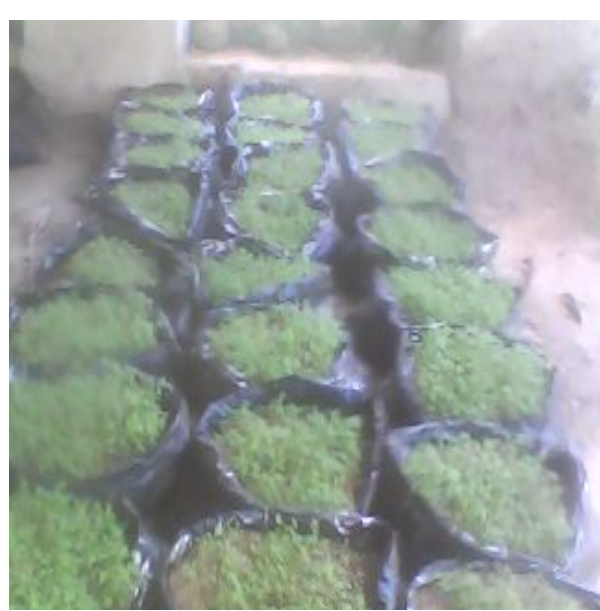

(a)

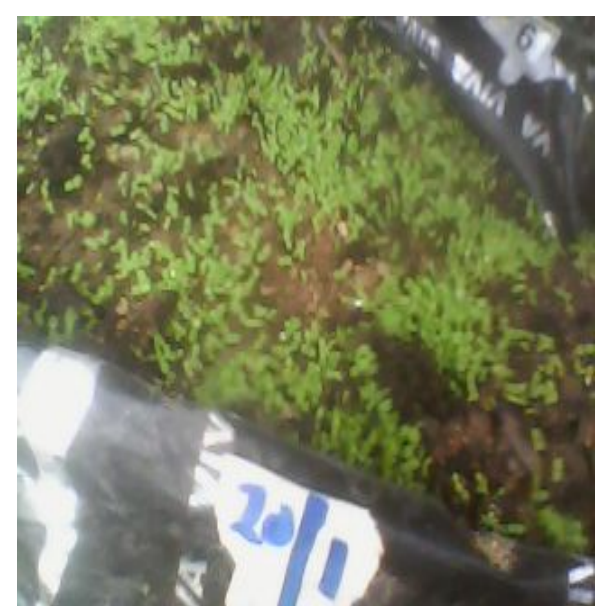

(b)

Figure 2. Artemisia seedlings at pre-nursery stage. 
Table 1. Effect of treatments on germination during raining season trial.

\begin{tabular}{|c|c|c|c|c|c|}
\hline Treatment & Days to Germination & Vigor & Germination \% & Shoot Length & Root Length \\
\hline \multicolumn{6}{|l|}{ GA3 } \\
\hline 100 pp/6hrs & 3.67 hij & 2.00 ef & $73.67 \mathrm{~d}$ & 1.98 abcdef & $0.48 \mathrm{f}$ \\
\hline $100 \mathrm{pp} / 12 \mathrm{hrs}$ & $2.67 \mathrm{jkl}$ & $1.33 \mathrm{f}$ & $63.50 \mathrm{~h}$ & $2.48 \mathrm{f}$ & $0.53 \mathrm{f}$ \\
\hline $100 \mathrm{pp} / 24 \mathrm{hrs}$ & 3.33 hijk & $1.33 \mathrm{f}$ & $81.00 \mathrm{~b}$ & 2.67 abcdef & 0.48 abcde \\
\hline 300 pp/6hrs & 3.67 hij & 2.33 de & $57.50 \mathrm{k}$ & 2.62 abcde & 0.53 abcde \\
\hline $300 \mathrm{pp} / 12 \mathrm{hrs}$ & 3.67 hij & $3.33 \mathrm{bc}$ & 49.67 no & 2.51abc & 0.58 abcde \\
\hline $300 \mathrm{pp} / 24 \mathrm{hrs}$ & 3.67 hij & $4.33 \mathrm{a}$ & $26.83 \mathrm{u}$ & 2.11 bcdef & 0.58 abcde \\
\hline 500 pp/6hrs & $5.00 \mathrm{efg}$ & $3.33 \mathrm{bc}$ & $37.83 \mathrm{r}$ & $2.57 \mathrm{def}$ & 0.58 abcde \\
\hline $500 \mathrm{pp} / 12 \mathrm{hrs}$ & 5.00 efg & $3.33 \mathrm{bc}$ & 48.83 o & 2.43 abcdef & 0.60 abcde \\
\hline $500 \mathrm{pp} / 24 \mathrm{hrs}$ & $0.00 \mathrm{~m}$ & $0.00 \mathrm{~g}$ & $0.00 \mathrm{w}$ & 0.00 abcdef & 0.60 abcde \\
\hline \multicolumn{6}{|l|}{ Cold Water } \\
\hline 2 hours & $2.33 \mathrm{kl}$ & 4.33 a & $58.83 \mathrm{j}$ & 2.32 abcdef & 0.55 abcde \\
\hline 4 hours & 4.00 ghi & 3.67abc & $45.33 \mathrm{p}$ & $2.99 \mathrm{a}$ & 0.60 abcde \\
\hline 6 hours & 3.33 hijk & $4.33 \mathrm{a}$ & $42.37 \mathrm{q}$ & 2.31 abcdef & 0.61 abcde \\
\hline \multicolumn{6}{|l|}{ Sulphuric Acid } \\
\hline $10 \% / 1 \mathrm{~min}$ & 4.67 ghi & 1.67 ef & 95.50 a & 2.36 abcdef & 0.64 abcdd \\
\hline $10 \% / 2 \mathrm{mins}$ & 4.00 ghi & 2.33 de & 70.17 e & 2.22 abcdef & $0.61 \mathrm{abc}$ \\
\hline $10 \% / 3$ mins & $2.33 \mathrm{kl}$ & $3.00 \mathrm{~cd}$ & $51.00 \mathrm{~m}$ & 2.74 bcdef & 0.62 abcd \\
\hline $20 \% / 1 \mathrm{~min}$ & 3.67 hij & $2.33 \mathrm{de}$ & $58.33 \mathrm{jk}$ & 2.46 abcd & $0.61 \mathrm{abc}$ \\
\hline $20 \% / 2 \mathrm{mins}$ & $8.67 \mathrm{a}$ & 3.33 bc & $50.67 \mathrm{~nm}$ & 2.83 abcdef & $0.62 \mathrm{abc}$ \\
\hline $20 \% / 3$ mins & 6.00 de & $4.00 \mathrm{ab}$ & $25.67 \mathrm{u}$ & $2.25 a b c$ & $0.61 \mathrm{abc}$ \\
\hline $30 \% / 1 \mathrm{~min}$ & $6.33 \mathrm{~cd}$ & $4.33 \mathrm{a}$ & $21.00 \mathrm{v}$ & 2.57 bcdef & $0.56 \mathrm{abc}$ \\
\hline $30 \% / 2 \operatorname{mins}$ & $2.33 \mathrm{kl}$ & $1.67 \mathrm{ef}$ & $65.67 \mathrm{gf}$ & 2.05 abcdef & 0.55 abcde \\
\hline $30 \% / 3$ mins & 5.33 def & $3.33 \mathrm{bc}$ & $41.17 \mathrm{q}$ & $2.20 \mathrm{ef}$ & 0.55 abcde \\
\hline \multicolumn{6}{|l|}{ Warm Water } \\
\hline $20^{\circ} \mathrm{C} / 1 \mathrm{~min}$ & $8.00 \mathrm{ab}$ & $4.33 \mathrm{a}$ & $21.67 v$ & 2.87 bcdef & 0.52 abcde \\
\hline $20^{\circ} \mathrm{C} / 2 \mathrm{mins}$ & $2.67 \mathrm{jkl}$ & 2.33 de & 55.831 & 2.41 abcdef & 0.56 abcdef \\
\hline $20^{\circ} \mathrm{C} / 3$ mins. & $7.33 \mathrm{fgh}$ & $3.67 \mathrm{abc}$ & $30.83 \mathrm{t}$ & $2.86 \mathrm{ab}$ & 0.58 abcde \\
\hline $40^{\circ} \mathrm{C} / 1 \mathrm{~min}$ & $4.33 \mathrm{ghf}$ & 3.67ab & $35.50 \mathrm{~s}$ & $2.52 \mathrm{abc}$ & 0.60 abcde \\
\hline $40^{\circ} \mathrm{C} / 2 \mathrm{mins}$ & $2.33 \mathrm{kl}$ & $2.33 \mathrm{de}$ & $60.83 \mathrm{i}$ & 2.65 abcdef & 0.55 abcd \\
\hline $40^{\circ} \mathrm{C} / 3 \mathrm{mins}$ & $3.00 \mathrm{ijkl}$ & $1.33 \mathrm{f}$ & $66.17 \mathrm{gf}$ & 2.46 abcde & 0.60 abcde \\
\hline $60^{\circ} \mathrm{C} / 1 \mathrm{~min}$ & $2.67 \mathrm{jkl}$ & 1.67 ef & $65.17 \mathrm{~g}$ & 2.59 abcdef & 0.61 abcde \\
\hline $60^{\circ} \mathrm{C} / 2 \mathrm{mins}$ & $2.00 \mathrm{l}$ & $2.00 \mathrm{f}$ & $66.67 \mathrm{f}$ & 2.62 abcdef & 0.68 abcd \\
\hline $60^{\circ} \mathrm{C} / 3 \mathrm{mins}$ & $2.67 \mathrm{jkl}$ & $1.33 \mathrm{f}$ & $72.67 \mathrm{~d}$ & 2.54 abcdef & $0.65 \mathrm{a}$ \\
\hline Control & 3.67 hij & $2.33 \mathrm{de}$ & $75.50 \mathrm{c}$ & 2.53 abcdef & $0.45 \mathrm{ab}$ \\
\hline
\end{tabular}

Means within a column followed by the same letter are not significantly different $(\mathrm{p}=0.05)$. 
Table 2. Effect of treatments on germination during the Irrigation trial.

\begin{tabular}{|c|c|c|c|c|c|}
\hline Treatment & Days to Germination & Vigor & Germination \% & Shoot Length & Root Length \\
\hline \multicolumn{6}{|l|}{ GA3 } \\
\hline $100 \mathrm{pp} / 6 \mathrm{hrs}$ & $3.33 \mathrm{klm}$ & 2.33 def & $61.17 \mathrm{~h}$ & 1.90 abcdefg & $0.38 \mathrm{~b}$ \\
\hline $100 \mathrm{pp} / 12 \mathrm{hrs}$ & $3.00 \mathrm{nml}$ & 2.33 def & $78.50 \mathrm{~d}$ & 1.64 abcdefg & $0.41 \mathrm{~b}$ \\
\hline $100 \mathrm{pp} / 24 \mathrm{hrs}$ & 4.67 ghi & $3.00 \mathrm{~h}$ & $60.50 \mathrm{k}$ & 2.10 abcdefg & $0.48 \mathrm{ab}$ \\
\hline 300 pp/6hrs & $6.00 \mathrm{fe}$ & $4.33 \mathrm{a}$ & $52.00 \mathrm{k}$ & 0.56 abcdefg & $0.50 \mathrm{c}$ \\
\hline $300 \mathrm{pp} / 12 \mathrm{hrs}$ & 6.33 de & $4.33 \mathrm{a}$ & $46.17 \mathrm{~m}$ & $1.78 \mathrm{~g}$ & $0.48 \mathrm{~b}$ \\
\hline $300 \mathrm{pp} / 24 \mathrm{hrs}$ & $5.33 \mathrm{fg}$ & 3.33abcd & $50.83 \mathrm{kl}$ & 1.67 abcdefg & $0.51 \mathrm{~b}$ \\
\hline $500 \mathrm{pp} / 6 \mathrm{hrs}$ & $5.00 \mathrm{gh}$ & 2.67 cdef & $55.00 \mathrm{j}$ & 1.93 abcdef & $0.51 \mathrm{~b}$ \\
\hline $500 \mathrm{pp} / 12 \mathrm{hrs}$ & $7.00 \mathrm{~cd}$ & 2.67 cdef & $84.67 \mathrm{~b}$ & $1.67 \mathrm{~h}$ & $0.53 \mathrm{~b}$ \\
\hline $500 \mathrm{pp} / 24 \mathrm{hrs}$ & $6.00 \mathrm{ef}$ & $1.67 \mathrm{fg}$ & $27.17 \mathrm{q}$ & 1.71 abcdefg & $0.52 \mathrm{~b}$ \\
\hline \multicolumn{6}{|l|}{ Cold Water } \\
\hline 2 hours & 4.33 hij & 2.00 efg & 75.67 e & $2.21 \mathrm{efg}$ & $0.55 \mathrm{ab}$ \\
\hline 4 hours & 3.33 klm & 2.33 def & 90.83 a & 1.97 abcdefg & $0.55 \mathrm{~b}$ \\
\hline 6 hours & $5.33 \mathrm{fg}$ & 2.67 cdef & $60.83 \mathrm{~h}$ & 1.86 abcdefg & $0.56 \mathrm{~b}$ \\
\hline \multicolumn{6}{|l|}{ Sulphuric Acid } \\
\hline $10 \% / 1 \mathrm{~min}$ & 4.67 ghi & 2.33 def & $84.00 \mathrm{~b}$ & 1.79 abcdefg & $0.58 \mathrm{~b}$ \\
\hline $10 \% / 2 \mathrm{mins}$ & $7.00 \mathrm{~cd}$ & 2.67 cdef & 80.83 c & 2.00 bcdef & $0.58 \mathrm{~b}$ \\
\hline $10 \% / 3 \mathrm{mins}$ & $2.67 \mathrm{~nm}$ & 2.33 def $^{`}$ & $61.17 \mathrm{~h}$ & $1.91 \mathrm{a}$ & $0.58 \mathrm{~b}$ \\
\hline $20 \% / 1 \min$ & $4.33 \mathrm{hij}$ & $4.33 \mathrm{a}$ & 50.001 & 1.83 bcdefg & $0.59 \mathrm{~b}$ \\
\hline $20 \% / 2$ mins & $2.67 \mathrm{~nm}$ & 3.67 abc & $31.33 \mathrm{p}$ & 2.26 abcdefg & $0.57 \mathrm{ab}$ \\
\hline $20 \% / 3$ mins & $13.00 \mathrm{a}$ & $3.67 \mathrm{abc}$ & $30.83 \mathrm{p}$ & 1.98 cdefg & $0.58 \mathrm{~b}$ \\
\hline $30 \% / 1 \mathrm{~min}$ & $13.00 \mathrm{a}$ & 3.33abcd & 35.33 о & 1.79 abcde & $0.55 \mathrm{~b}$ \\
\hline $30 \% / 2 \mathrm{mins}$ & $3.33 \mathrm{klm}$ & $4.00 \mathrm{ab}$ & $51.17 \mathrm{kl}$ & 1.94 bcdefg & $0.55 \mathrm{~b}$ \\
\hline $30 \% / 3$ mins & $7.33 \mathrm{c}$ & $4.33 \mathrm{a}$ & $46.17 \mathrm{~m}$ & 1.86 abcd & $0.55 \mathrm{a}$ \\
\hline \multicolumn{6}{|l|}{ Warm Water } \\
\hline $20^{\circ} \mathrm{C} / 1 \mathrm{~min}$ & $13.00 \mathrm{a}$ & $4.33 \mathrm{a}$ & $32.17 \mathrm{p}$ & 2.87 bcdefg & $0.52 \mathrm{a}$ \\
\hline $20^{\circ} \mathrm{C} / 2 \mathrm{mins}$ & $3.67 \mathrm{jkl}$ & $4.00 \mathrm{ab}$ & $54.50 \mathrm{j}$ & 2.16 abcdefg & $0.56 \mathrm{ab}$ \\
\hline $20^{\circ} \mathrm{C} / 3 \mathrm{mins}$ & $10.67 \mathrm{~b}$ & 3.33abcd & $55.67 \mathrm{j}$ & $2.11 \mathrm{gf}$ & $0.58 \mathrm{ab}$ \\
\hline $40^{\circ} \mathrm{C} / 1 \mathrm{~min}$ & $7.33 \mathrm{c}$ & $4.00 \mathrm{ab}$ & $38.83 \mathrm{n}$ & 1.82 efg & $0.60 \mathrm{~b}$ \\
\hline $40^{\circ} \mathrm{C} / 2 \mathrm{mins}$ & 3.33 klm & 3.33abcd & $58.50 \mathrm{i}$ & $1.98 \mathrm{ab}$ & $0.56 \mathrm{~b}$ \\
\hline $40^{\circ} \mathrm{C} / 3$ mins & $4.33 \mathrm{hij}$ & 2.67 cdef & $60.67 \mathrm{~h}$ & 2.04 abcdefg & $0.60 \mathrm{~b}$ \\
\hline $60^{\circ} \mathrm{C} / 1 \mathrm{~min}$ & $3.33 \mathrm{klm}$ & 2.67 cdef & $68.33 \mathrm{~g}$ & 1.97 abcdefg & $0.61 \mathrm{~b}$ \\
\hline $60^{\circ} \mathrm{C} / 2 \mathrm{mins}$ & $2.33 n$ & $1.67 \mathrm{fg}$ & $71.50 \mathrm{f}$ & $2.16 \mathrm{abc}$ & $0.68 \mathrm{ab}$ \\
\hline $60^{\circ} \mathrm{C} / 3 \mathrm{mins}$ & $2.67 \mathrm{~nm}$ & $1.00 \mathrm{~g}$ & $72.50 \mathrm{f}$ & 2.04 abcdefg & $0.65 \mathrm{~b}$ \\
\hline Control & $4.00 \mathrm{ijk}$ & 3.00 bcde & $50.83 \mathrm{kl}$ & 1.85 abcdefg & $0.46 \mathrm{~b}$ \\
\hline
\end{tabular}

Means within a column followed by the same letter are not significantly different $(p=0.05)$. 


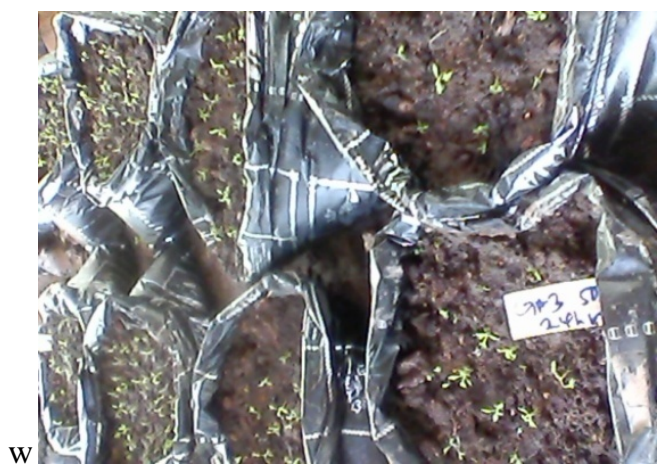

(a)

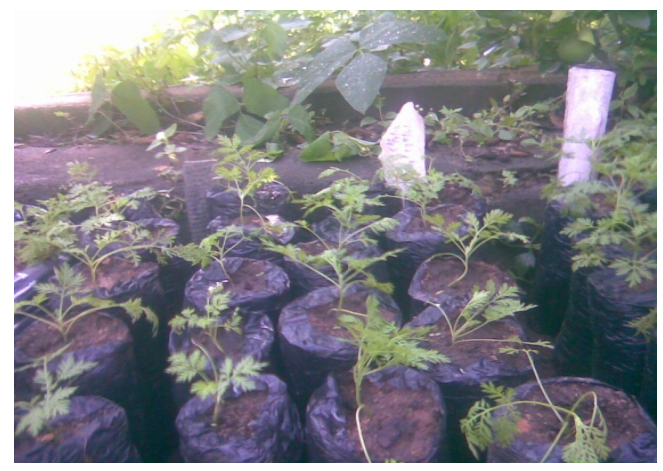

(b)

Figure 3. Artemisia seedlings at the nursery stage.

Germination of seeds of A. annua, commenced 2 - 3 days after sowing and $96 \%$ of the seeds responded to treatment. This is contrary to the findings of [25] and other workers who observed that seeds of A. annua and $A$. absinthium germinated in 6 - 7 days as obtained when grown under field conditions.

The insignificant height observed with the Artemisia young seedlings may be attributed to lack of ample reserved nutrients such as Carbohydrate, lipid and protein to enable the seedlings achieve critical size advantage [26].

\section{Conclusion}

Using warm water is a simple and affordable treatment especially to local farmers which will give the best result in the germination and seedling production of A. annua. In Nigeria, early March is recommended as the ideal planting period so that seedlings are transplanted on the field at the onset of rainfall.

\section{Acknowledgements}

The authors express their appreciation to the Artemisia Programme of Institute for Agricultural Research, Ahmadu Bello University Zaria, Nigeria for financial and technical support during this research. In addition, we would like to thank Dr. I.S Usman (Head of Plant Science Department, ABU Zaria, Mal. Muhd Sani Usman, Mal. Muhammad Ja'afar Sulaiman and Hamza Ado Bomo and my children Abdulbasit, Abdusslam, Muhammad, Abdulmalik, Abdulmajid and Abdul'Azeez for their support and cooperation during the field experiment.

\section{References}

[1] Ferreira, J.F.S. and Janick, J. (2002) Production of Artemisinin from in Vitro Cultures of Artemisia annua L. In: Biotechnology in Agriculture and Forestry Vol. 51, Springer-Verlag, Berlin, 1-12.

[2] Duke, S.O., Vaughn, K.C., Croom, E.M.J. and Elsohly, H.N. (1987) Artemisinin, a Constituent of Annual Wormwood (Artemisia annua) Is a Selsctive Phytotoxin. Weed Science, 35, 499-505.

[3] Paniego, N.B. and Giulietti, A.M. (1994) Artemisia annua L.: Dedifferentiated and Differentiated Cultures. Plant Cell, Tissue and Organ Culture, 36, 163-168. http://dx.doi.org/10.1007/BF00037715

[4] Zare, A.R., Solouki, M., Omidi, M., Irvani, N., Oladzad, A.A. and Mahdi Nezad, N. (2011) Effect of Various Treatments on Seed Germination and Dormancy Breaking in Ferula assa foetida L. (Asafetida), a Threatened Medicinal Herb. Trakia Journal of Sciences, 9, 57-61.

[5] Karam, N.S. and Al-Salem, M.M. (2001) Breaking Dormancy in Arbutus andrachna L. Seeds by Stratification and Gibberellic Acid. Seed Science and Technology, 29, 51-56.

[6] Martinez-Gomez, P. and Dicenta, F. (2001) Mechanism of Dormancy in Seeds of Peach (Prunus persica Batsch) cv.GF305. Scientia Horticulturae, 91, 51-58. http://dx.doi.org/10.1016/S0304-4238(01)00235-7

[7] Jensen, M. and Eriksen, E.N. (2001) Development of Primarydormancy in Seeds of Prunus avium during Maturation. Seed Science and Technology, 29, 307-320.

[8] Al-Quadan, F., Ibrahim, A. and Al-Charchafchi, F.M.R. (2008) Effect of Chlorogenic and Caffeic Acids on Activities and Isoenzymes of G6PDH and 6PGDH of Artemisia Herba Alba Seeds Germinated for One and Three Days in Light 
and Dark. Jordan Journal of Biological Sciences, 1, 85-88.

[9] Ferreira, J.F.S. and Janick, J. (1997) Artemisia annua: Botany, Horticulture, Pharmacology. In: Janick, J., Ed., Horticultural Reviews, John Wiley \& Sons, Inc., Hoboken, Vol. 19: 319-371.

[10] Wiese, A.M. and Binning, L.K. (1987) Calculating the Threshold Temperature of Development for Weeds. Weed Science, 35, 177-179.

[11] Gibson, M.S. (1980) Measurement of Vigor in Seeds or Seedlings. Sugarbeet Research and Extension Reports, 11, 143-147.

[12] Geraldine, L.D. and Lisa, A.D. (1999) Water Potential and Ionic Effects on Germination and Seedling Growth of Two Cold Desert Shrubs. American Journal of Botany, 86, 1146-1153. http://dx.doi.org/10.2307/2656978

[13] Nicolas, G. (2003) The Biology of Seeds Recent Research Advances: Proceedings of the Seventh International Workshop on Seeds, Salamanca, Spain 2002. CABI Pub. Page, Wallingford.

[14] Taylor, O.J., Green, N.P.O. and Stout, G.W. (1997) Biological Science. Cambridge University Press, Cambridge, 984.

[15] Style, M.L.A. (2008) Plant Development. Encyclopedia Britanica, Ultimatte Reference Suit, Chicago, 8-9.

[16] Mott, J.J. and Groves, R.H. (1981) Germination Strategies. In: Pate, J.S. and Comb, A.J.Mc., Eds., The Biology of Australian Plants, University of Western Australian Press, Crawley, 307-341.

[17] Bewley, J.D. and Black, M. (1994) Seeds: Physiology of Development and Germination. In: The Language of Science. 2nd Edition, Plenum Press, New York, 445-446.

[18] Ferreira, J. and Janick, J. (2009) Annual Wormwood (Artemisia annua L.). www.hort.purdue.Edu/newcrop/cropfactsheets/Artemisia.pdf

[19] Auld, D.L., Bettis, B.L., Crock, J.E. and Kephart, D. (1988) Planting Date and Temperature Effects on Germination, and Seed Yield of Chickpea. Agronomy Journal, 80, 909-914. http://dx.doi.org/10.2134/agronj1988.00021962008000060014x

[20] Moore, M. (1979) Medicinal Plants of the Mountain West. Museum of New Mexico Press, Santa Fe.

[21] Osborne, D.J., McManus, M.T. and Webb, J. (1985) 17-Target Cells for Ethylene Action. In: Roberts, J.A. and Tucker, G.A., Eds., Ethylene and Plant Development, Butterworth, London, 197-212. http://dx.doi.org/10.1016/B978-0-407-00920-2.50021-4

[22] Basking, C.C. and Basking, J.M. (1995) Dormancy Types and Dormancy-Breaking and Germination Requirements in Seeds of Halophytes. In: Khan, M.A. and Ungar, I.A., Eds., Biology of Salt Tolerant Plants, University of Karachi, Karachi, 23-30.

[23] Modares Hashemi, M. (2003) Loss of Dormancy and Raising of 8 Slat Desert Species and Their Manner of Establishment in the Site, a Research Plan Report. Research Institute of Forests and Rangelands, Tehran.

[24] Jamaleddine, Z.O., Lyam, P., Fajimi, O., Giwa, A., Aina, A., Lawyer, E.F., Okere, A.U. and Odofin, W.T. (2011) In Vitro Growth Response of Artemisia annua Seeds to Different Concentrations of Plant Growth Regulators. African Journal of Biotechnology, 10, 17841-17844. http://dx.doi.org/10.5897/AJB10.1289

[25] Mannan, A., Syed, T.N., Yameen, M.A., Ullah, N., Ismail, T., Hussain, I. and Mirza, B. (2012) Effect of Growth Regulators on in Vitro Germination of Artemisia absinthium. Scientific Research and Essays, 7, 1501-1507. http://dx.doi.org/10.5897/SRE11.1894

[26] Micheal, F. (1993) Seed Ecology. Chapman and Hall, 2-6 Boundary Row, London, 208. 